\title{
Przestrzenne zróżnicowanie poziomu rozwoju regionalnego w Unii Europejskiej w świetle wybranych mierników
}

\section{WPROWADZENIE}

Pojęcie rozwoju opiera się na gruncie takich kategorii przedmiotowych, jak zmiana i struktura. Rozwój jest zatem pewnym ciagiem zmian ukierunkowanych i nieodwracalnych dokonujących się w strukturze obiektów złożonych, tj. systemów. Zmiany te mogą dotyczyć aspektu ilościowego, a więc zwiększenia lub zmniejszenia pewnych cech obiektu, jak również aspektu jakościowego, tj. powstawania nowych własności obiektu. Rozwój gospodarczy jest szerszym pojęciem niż wzrost gospodarczy, przez który rozumie się zwiększenie zdolności do wytwarzania dóbr i usług i odnosi się tylko do zmian ilościowych. W wyniku rozwoju gospodarczego dokonują się przemiany o charakterze długofalowym, obejmujące nie tylko wzrost poziomu produkcji i zatrudnienia czy zwiększenie napływu inwestycji, ale także przemiany o charakterze jakościowym i strukturalnym, dotyczące zmiany organizacji społeczeństw, podniesienia poziomu życia ludności oraz zwiększenia bezpieczeństwa publicznego i socjalnego (Kuciński 2009). Zróżnicowania przestrzenne poziomu rozwoju gospodarczego i społecznego poszczególnych obszarów mają charakter obiektywny i wynikają między innymi ze zróżnicowań samej przestrzeni geograficznej (Szymla 2000, 2005).

Rozwój regionalny można rozumieć jako nieodwracalne zmiany ilościowo-jakościowe zmierzające do osiagania trwałego wzrostu potencjału społeczno-gospodarczego i kulturowego regionu (Kudełko 2005). Innymi słowy, rozwój regionalny to wzrost potencjału gospodarczego regionów oraz trwała poprawa ich konkurencyjności i poziomu życia ich mieszkańców, co przyczynia się do rozwoju społeczno-gospodarczego kraju. Konkurencyjność regionu to miara jakościowa jego rozwoju społeczno-gospodarczego, ocenianego na tle innych jednostek, z punktu widzenia jego zdolności do skutecznej rywalizacji w istniejących warunkach (krajowych, europejskich, światowych). Głównymi elementami wzrostu regionu są: wzrost gospodarczy i tworzenie miejsc pracy, wzrost dobrobytu i jakości życia ludności, wzrost atrakcyjności inwestycyjnej, rozwój technologiczny i innowacje, restrukturyzacja sektorów gospodarczych, rozwój usług i zasobów społecznych, wzrost ruchliwości zawodowej, społecznej i przestrzennej, rozwój infrastruktury instytucjonalnej i rynkowego otoczenia biznesu, poprawa jakości środowiska naturalnego oraz wzbogacenie tożsamości regionalnej i procesy integracyjne (Klasik, Kuźnik 2001, Kudłacz 1999, Szymla 2005). 
Celem działań Unii Europejskiej jest dążenie do zredukowania różnic w poziomie rozwoju poszczególnych regionów i zmniejszenia zacofania najbardziej peryferyjnych regionów i wysp, w tym terenów wiejskich. W wyniku traktatu z Maastricht w 1992 r. ustanowione zostały instrumenty (Fundusz Spójności) oraz polityki (polityka spójności), których wspólnym celem jest zmniejszanie (asymetrii) dysproporcji w rozwoju regionów oraz podnoszenie ich konkurencyjności. (Gawlikowska-Hueckel 2002, Głąbicka 2004, Gawlikowska-Hueckel, Zielińska-Głębocka 2004). Od 2007 r. trzema głównymi priorytetami w ramach polityki spójności UE są konwergencja, czyli wspieranie wzrostu gospodarczego i tworzenia miejsc pracy w regionach najsłabiej rozwiniętych; podnoszenie konkurencyjności i zatrudnienia w bogatszych regionach w aspekcie globalizacji i przechodzenia do gospodarki opartej na wiedzy; spójność terytorialna, czyli wspieranie ściślejszej integracji terytorium Unii we wszystkich jego wymiarach w celu zrównoważonego i trwałego rozwoju na poziomie współpracy transgranicznej, ponadnarodowej i międzyregionalnej (European Commission, 2005a). Termin „spójność” posiada wiele znaczeń i rozpatrywany jest w różnych aspektach. Według jednej z definicji, pojęcie spójności używane jest do określenia nierówności między regionami oraz krajami uczestniczącymi w procesie integracji i rozumiane jako stopień, do którego rozbieżności w zakresie dobrobytu społecznego i gospodarczego między różnymi regionami bądź też grupami w obrębie Wspólnoty są politycznie i społecznie tolerowalne (Molle 2000). Zatem przyjąć można, że powiększanie się dysproporcji w rozwoju regionalnym oznacza zmniejszanie się spójności, natomiast zmniejszanie zróżnicowania w rozwoju regionalnym interpretowane może być jako zwiększanie spójności. Ważną rolę w dążeniu do spójności odgrywają studia diagnostyczne, pozwalające na coraz bardziej precyzyjne poznawanie stopnia różnicowania przestrzennego kluczowych sektorów gospodarki, a także życia społecznego i kulturowego. Określenie prawidłowości w tym zakresie jest niezbędne do podejmowania działań na rzecz rozwoju układów regionalnych prowadzących do kształtowania się gospodarki opartej na wiedzy oraz dążenia do podniesienia jej konkurencyjności (Zioło 2009).

Spośród wielu mierników rozwoju regionalnego ostatnio zwraca się uwagę na wskaźniki stanu społeczeństwa informacyjnego (SI) w aspekcie technologicznym, ekonomicznym i społecznym. Społeczeństwo informacyjne jest nowym zjawiskiem, które wpływa na rozwój regionalny, a jego głównymi elementami są gospodarka oparta na wiedzy (GOW) oraz stopień wykorzystania i dostępności TIT (Technologii Informacyjnej i Telekomunikacji; ESPON 2007). Do wykorzystywanych indeksów syntetycznych określających terytorialny rozwój społeczeństwa informacyjnego należy m.in. złożony indeks społeczeństwa informacyjnego obliczony w oparciu o cząstkowy indeks e-EUROPA (INSEAD 2004) oraz wskaźnik gotowości sieciowej (Network Readiness Index NRI; World Economic Forum 2009), interpretowane w odniesieniu do koncepcji cyklu życia OECD - gotowości, intensywności i oddziaływania. Do cząstkowych wskaźników należą tu m.in. dochód rozporządzalny gospodarstw domowych, zasoby ludzkie w nauce i technologii, gospodarstwa domowe ze stacjonarną linią telefoniczna, z przynajmniej jednym telefonem komórkowym, z komputerem osobistym, z dostępem do Internetu (w tym szerokopasmowym). Ponadto w analizie wykorzystuje się mierniki określające dostęp do sieci światłowodowej, dostęp firm do Internetu i posiadających własną stronę internetową oraz zatrudnienie w sektorach technologii i wiedzochłonnych, wydatki na sektor B\&R i zastosowanie patentów TIT. W wymiarze społecznym wskaźniki rozwoju społeczeństwa informacyjnego mogą obejmować dostęp do usług on-line w administracji, edukacji, bankowości oraz handlu. Nie ma jednolicie skonstruowanych uniwersalnych wskaźników określających stopień efektywności społeczeństwa infor- 
macyjnego i jego zróżnicowania regionalnego, a dużym problemem jest także dostępność danych na szczeblu regionalnym.

Do ważkich mierników rozwoju regionalnego we współczesnej Europie należy zaliczyć wskaźniki demograficzne. Spadek dynamiki demograficznej, którego przejawem jest proces starzenia się ludności, zmniejszenie dzietności poniżej poziomu gwarantującego zastępowalność pokoleń oraz ubytek naturalny i wędrówkowy ludności prowadzi w efekcie do natężenia procesów depopulacyjnych (Kurek 2008a, 2008b). Negatywne przemiany demograficzne z kolei mogą prowadzić do osłabienia regionalnych możliwości rozwojowych w dłuższym okresie. Procesy wyludniania dotyczą nie tylko obszarów wiejskich i peryferyjnie położonych, ale także poprzemysłowych i niektórych regionów centralnie położonych. Jednym z proponowanych rozwiązań zahamowania procesu starzenia się ludności są migracje kompensacyjne (replacement migration), jako że w celach zarobkowych migrują głównie ludzie młodzi. Jednak na dłuższą metę rozwiązanie takie jest nie do przyjęcia, gdyż Europa musiałaby przyjąć zbyt wielu imigrantów, co mogłoby doprowadzić do napięć społecznych (Coleman 1992, 2002; Lesthaeghe 2000). Badania pokazały, że aby utrzymać poziom starości demograficznej na obecnym poziomie (rozumiany tu przez stosunek liczby osób w wieku produkcyjnym 15-64 lat do liczby osób w wieku poprodukcyjnym - 65 lat i więcej, znany w literaturze jako tzw. współczynnik potencjalnego wsparcia), to kraje Unii Europejskiej do 2050 r. musiałyby przyjać około 700-800 mln imigrantów (czyli blisko $20 \mathrm{mln}$ rocznie), a wszystkie kraje europejskie niemal dwukrotnie więcej (UN 2000, Saczuk 2003, Bijak i in. 2008). Należy tu wspomnieć że obecnie migracja zagraniczna netto do krajów UE wynosi około 1,5 mln osób (w 2008 r.).

Dlatego też rekomendacje dla polityki regionalnej koncentrują się głównie na działaniach związanych ze zwiększeniem aktywności zawodowej, w tym zwiększeniem udziału kobiet na rynku pracy, stopniowym podnoszeniem granicy wieku przechodzenia na emeryturę, reformowaniem systemu zabezpieczeń społecznych, promocją aktywnej starości poprzez zwiększenie aktywności zawodowej w grupie emerytów oraz szeregiem rozwiązań umożliwiających pogodzenie kariery zawodowej z wychowywaniem dzieci (European Commission 2002, 2004, 2005b, Avramov, Maskova 2004). Pomimo powyższych uwarunkowań saldo migracji może być dobrym miernikiem rozwoju regionalnego, ze względu na fakt, iż ludność przemieszcza się z mniej do bardziej uprzywilejowanych obszarów, np. z peryferyjnych obszarów wiejskich do obszarów metropolitalnych, między wschodnią i zachodnią Europą oraz z innych kontynentów. Z drugiej strony, obszary o przyjaznym otoczeniu i atrakcyjności klimatycznej przyciągają osoby starsze (np. wybrzeże śródziemnomorskie).

Kolejnym miernikiem demograficznym odzwierciedlającym poziom rozwoju regionalnego Europy jest wskaźnik dzietności ogólnej (total fertility rate) bądź współczynnik przyrostu naturalnego. Obecnie korzystniejszymi wskaźnikami w zakresie dzietności i rozrodczości charakteryzują się bogatsze regiony Europy Północnej i Zachodniej, a to ze względu na odpowiednią politykę rodzinną (Kurek 2008c). Innymi wskaźnikami demograficznymi obrazującymi zróżnicowanie regionalne mogą być także przeciętna długość życia (większa w regionach wysoko rozwiniętych ze względu na lepszą opiekę medyczną zdrowszy styl życia i lepsze odżywianie) oraz wspomniany wyżej współczynnik potencjalnego wsparcia, ilustrujący relacje ekonomiczne pomiędzy ludnością produkcyjną i poprodukcyjną, co ma znaczenie ze względu na wydolność systemów emerytalnych.

Zestawiając wybrane tu wskaźniki demograficzne możemy mówić o rozwoju demograficznym regionów, gdzie obszary o dużym ubytku naturalnym i wędrówkowym ludności 
i niekorzystnej strukturze wiekowej są wyzwaniem dla polityki regionalnej w aspekcie ekonomicznym i społecznym w celu zwiększenia ich atrakcyjności oraz zapewnienia istotnych usług mających wpływ na warunki życia ich mieszkańców. Na drugim biegunie znajdują się regiony prężne demograficznie o przewadze napływu ludności nad odpływem i często o dodatnim przyroście naturalnym. Są to zwykle obszary metropolitalne o bogatej ofercie rynku pracy, szerokim dostępie do rozmaitych usług oraz rozwiniętej infrastrukturze w zakresie Technologii Informacyjnej i Telekomunikacji.

Kolejna grupa mierników w zakresie rozwoju regionalnego dotyczy wskaźników społecznych. Kluczowe znaczenie ma tutaj poziom bezrobocia jako klasyczny wskaźnik opisujący stan regionalnego rynku pracy. Stopa bezrobocia może być interpretowana jako rozbieżność istniejąca pomiędzy kwalifikacjami zasobów siły roboczej a potrzebami rynku pracy, zmieniającymi się w zależności od cyklów koniunkturalnych. Do opisu regionalnego rynku pracy można się także posłużyć wskaźnikiem zatrudnienia ogółem (np. udział zatrudnionych w całkowitej liczbie ludności w wieku 15-64 lat, a także stopa zatrudnienia starszych pracowników w stosunku do ogółu zatrudnionych). Innym wskaźnikiem może być odsetek ludności z wyższym wykształceniem, świadczącym o jakości kapitału ludzkiego. Osoby z wyższym wykształceniem stanowią ważną grupę w gospodarce opartej na wiedzy. Grupę mierników społecznych stanowią też wskaźniki charakteryzujące dostęp do usług w zakresie ochrony zdrowia i opieki społecznej (m.in. liczba osób przypadających na 1 łóżko szpitalne, liczba lekarzy i pielęgniarek na 10 tys. mieszkańców, ośrodki pomocy społecznej itp.).

Dużą rolę w rozwoju regionów odgrywa ich dostępność transportowa, związana z koncepcją rdzeni i peryferii. Wykorzystać tu można szereg wskaźników opisujących stan infrastruktury drogowej, kolejowej czy lotniczej oraz przepływy towarów, usług i osób. Wreszcie istotnym aspektem rozwoju regionów są jego zasoby kulturowe i przyrodnicze, składające się na ich dziedzictwo kulturowe i przyrodnicze, a jednym z mierników określającym wykorzystanie tego potencjału jest natężenie ruchu turystycznego.

W niniejszym opracowaniu przedstawiono przestrzenne zróżnicowanie poziomu rozwoju regionów Europy w świetle przyjętych mierników cząstkowych obejmujących kwestie demograficzne, społeczne i gospodarcze uzyskane za pośrednictwem bazy Eurostat, w celu określenia kierunków rozwoju dysproporcji regionalnych. Ponadto podjęto próbę przeprowadzenia typologii rozwoju regionów w oparciu o taksonomiczną metodę analizy skupień. Zakres czasowy analizy obejmuje lata 2003-2007, w zależności od dostępności danych z bazy regionalnej Eurostatu. Dane więc obejmują sytuację sprzed kryzysu finansowego oraz w większości przypadków dotyczą okresu po poszerzeniu UE. Zakres przestrzenny analizy obejmuje jednostki NUTS2 podziału regionalnego Europy. Analiza koncentruje się głównie na regionach Unii Europejskiej, ale dla porównań wzięto pod uwagę także kraje EFTA (Szwajcaria, Islandia, Norwegia, Liechtenstein) oraz wybrane kraje kandydujące (Chorwacja), nie wzięto natomiast pod uwagę Turcji. Wybór taki uzasadniony jest układem prezentowanych danych w Eurostacie oraz większą spójnością terytorialną jednostek prezentowanych na kartogramach.

Do analizy wybrano metody analizy wielowymiarowej, których wykorzystanie umożliwia zastąpienie opisu badanych obiektów za pomocą wielu cech opisem przy użyciu jednej wielkości agregatowej, co pozwala nie tylko na uszeregowanie obiektów, podzielenie ich na grupy, ale także ukazanie skali zróżnicowania między obiektami.

W szczególności zastosowano miernik syntetyczny (taksonomiczny miernik rozwoju) oraz analizę skupień. Konstrukcja miernika syntetycznego oraz grupowanie obiektów 
na podstawie analizy skupień oparte zostały o następujące wielkości: x1 - współczynnik przyrostu naturalnego, x 2 - współczynnik salda migracji, x3 - współczynnik potencjalnego wsparcia (liczba osób w wieku 15-64 lat przypadająca na liczbę osób w wieku 65 lat i więcej), x4 - współczynnik zatrudnienia ogółem, x5 - współczynnik zatrudnienia w sektorach wysokich technologii i wiedzochłonnych, x6 - zatrudnienie w usługach finansowych i obsłudze rynku nieruchomości, x7 - aktywność zawodowa osób starszych, x8 - stopa bezrobocia, x9 - produkt regionalny brutto na mieszkańca, x10 - dochody gospodarstw domowych, x11 - wydatki na sektor B+R, x12 - liczba zgłoszonych patentów (na 1 mln mieszkańców), x13 - liczba lekarzy na 100 tys. mieszańców, x14 - gęstość sieci autostrad (na 100 km²), x15 intensywność ruchu turystycznego oraz x16 - dostęp do Internetu gospodarstw domowych. Miary te opisują sytuację gospodarczą i społeczno-demograficzną regionów i mają charakter stymulant, za wyjątkiem cechy określającej stopę bezrobocia, która jest destymulantą. Przyjęto, iż utworzony w ten sposób miernik syntetyczny ukazuje poziom rozwoju społeczno-ekonomicznego regionów.

Dane poddano normalizacji według wzorów:

$$
x_{i}^{\prime}=\frac{x_{i}-x_{\min }}{x_{\max }-x_{\min }} \text { dla stymulant oraz } x_{i}^{\prime}=\frac{x_{\max }-x_{i}}{x_{\max }-x_{\min }} \text { dla destymulant. }
$$

Po normalizacji zmiennych macierze cech diagnostycznych posłużyły do konstrukcji taksonomicznego miernika rozwoju, według następującego wzoru:

Do typologii regionów pod względem poziomu rozwoju przyjęto metodę k-średnich, należącą do metod optymalizacyjno-iteracyjnych, w których punktem wyjścia jest wstępny podział obiektów na k skupień. Według T. Grabińskiego $(1992,2003)$ podziału takiego można dokonać na podstawie oceny opartej na intuicji lub znajomości przedmiotu badań, wykorzystanie arbitralnie wybranej zmiennej do ustalenia klas wielkości obiektów lub przyjęcie jako podziału wstępnego grup otrzymanych dowolną metodą taksonomiczną (np. Warda). Z kolei A. Malina (2004) proponuje procedurę wyznaczania ilości skupień na podstawie obliczenia miar zróżnicowania wewnątrzgrupowego i międzygrupowego. Procedura tworzenia skupień w tego typu metodach polega na minimalizacji wariancji wewnątrzgrupowych i maksymalizacji wariancji międzygrupowych. Metoda k-średnich jest najpopularniejszą, należącą do tej grupy. Algorytm postępowania jest w niej następujący:

$$
z_{i}=\sum_{j=1}^{p} x_{i j}(i=\mathbf{1}, \ldots, m)
$$

1. Ustalenie maksymalne liczby iteracji, np. na 10 oraz liczby żądanych skupień $\mathrm{k}$.

2. Określenie wyjściowych k skupień, które tworzą jednostki równo oddalone od siebie w uporządkowaniu wynikającym z posortowania odległości Euklidesa pomiędzy wszystkimi jednostkami.

3. Obliczenie miary poprawności podziału jako sumy kwadratów odległości Euklidesa pomiędzy środkami ciężkości wyróżnionych grup.

4. Wyznaczenie odległości pierwszej nieprzydzielonej jednostki od środków ciężkości poszczególnych grup i zakwalifikowanie jej do grupy najbliżej położonej.

5. Przeliczenie środka ciężkości grup i miary poprawności podziału. Jeżeli uległa ona poprawie, to jednostka pozostaje w tej grupie, w przeciwnym wypadku zmiana nie zostaje dokonana i rozpatrywana jest następna jednostka. 
6. Kolejne iteracje przeprowadzane są dotąd, aż wszystkie jednostki zostaną przydzielone do poszczególnych grup albo aż do wyczerpania założonej liczby iteracji.

Wyniki analizy grupowania metodą k-średnich można zweryfikować, opisać, uszeregować i zinterpretować poprzez porównanie średnich wartości cech w podgrupach. Na podstawie odległości obiektów od środków ciężkości oraz odległości międzygrupowej można ocenić, na ile wydzielone skupienia są od siebie różne i które cechy je najbardziej różnicują. $\mathrm{W}$ niniejszym opracowaniu wydzielone skupienia uszeregowano w oparciu o produkt regionalny brutto na mieszkańca.

\section{ANALIZA POZIOMU ROZWOJU REGIONALNEGO}

W analizie przedstawiono zróżnicowanie poszczególnych mierników w regionach NUTS2, a następnie określono poziom rozwoju regionalnego na podstawie miernika syntetycznego i typologii rozwoju. W zakresie rozwoju demograficznego największymi wartościami współczynnika przyrostu naturalnego charakteryzowały się regiony stołeczne Londynu, Paryża, Brukseli, Oslo czy Sztokholmu oraz regiony położone w pn. Francji (np. Nord-Pas-de-Calais), Holandii (Flevoland - polder powstały w latach 1980. i stosunkowo niedawno zasiedlony), pd. Hiszpanii (Murcia) i Irlandii. W 132 spośród 279 badanych regionów zanotowano ubytek naturalny ludności, największy w regionach Bułgarii, byłej NRD, Łotwy oraz w niektórych regionach śródziemnomorskich. Pod względem salda migracji największe wartości zanotowano w regionach śródziemnomorskich Francji, Włoch (w części północnej) i Hiszpanii. Z jednej strony taki układ przestrzenny można interpretować atrakcyjnością turystyczną tych regionów i związaną z tym dużą liczbą ofert pracy, a z drugiej strony stosunkowo dużym napływem migrantów w wieku emerytalnym z zamożniejszych państw Europy Północnej czy Zachodniej związanym z atrakcyjnością klimatyczną. Obszary emigracyjne zlokalizowane są w regionach Europy Środkowo-Wschodniej, północnych regionach krajów skandynawskich (warunki naturalne) oraz regionach północnej Francji i środkowo-zachodnich Niemiec (regiony poprzemysłowe). Pod względem współczynnika potencjalnego wsparcia najkorzystniejsze relacje między ludnością produkcyjną a poproducyjną występowały na Wyspach Brytyjskich (Irlandia Północna, Londyn, Irlandia Południowa i Wschodnia), w holenderskim Flevoland (napływ ludności głównie produkcyjnej do nowego obszaru) oraz w regionach Europy Środkowo-Wschodniej, gdzie poziom starości demograficznej jest ciagle relatywnie niski w porównaniu z regionami zachodnimi i północnymi. Najniższe wartości tego wskaźnika pojawiły się w północnych Włoszech, środkowej i południowej Francji, Grecji oraz północnych Niemczech.

Najwyższymi wskaźnikami zatrudnienia ogółem charakteryzowały się najbardziej uprzemysłowione obszary Europy (Wielka Brytania, Holandia, południowa Szwecja i Finlandia, Dania, południowe Niemcy), natomiast najniższa aktywność zawodowa była notowana w południowych Włoszech oraz rolniczych i słabo zurbanizowanych regionach krajów Europy Środkowo-Wschodniej. Największe zatrudnienie w sektorach wysokiej technologii i wiedzochłonnych obejmuje obszary parków technologicznych i największych ośrodków naukowo-badawczych, a mianowicie w południowo-wschodniej Anglii, w dolinie Rodanu i Renu, południowych Niemczech oraz w regionach stołecznych. Najniższe wskaźniki zaobserwowano w Grecji, Portugalii, południowej Hiszpanii oraz Polsce, Rumunii i Bułgarii. 
Zatrudnienie w sektorach finansowym i obsłudze nieruchomości jest skoncentrowane na obszarze tzw. Europejskiego Banana o największej gęstości zaludnienia i koncentracji działalności gospodarczej, rozciągającym się od południowej Wielkiej Brytanii poprzez północną Francję, kraje Beneluksu, południowe Niemcy, Szwajcarię do północnych Włoch. Ponadto wysokie zatrudnienie w tych sektorach występuje w południowych regionach krajów skandynawskich oraz w regionach stołecznych. Najniższe wartości tego miernika zanotowano w Rumunii, Bułgarii, peryferyjnych regionach Polski, Węgier i Słowacji oraz w Grecji i Portugalii. Aktywność zawodowa osób starszych zależy m.in. od prowadzonej polityki społecznej w danych krajach (m.in. promowanie active ageing), wydolności systemów emerytalnych, wykonywanego wcześniej zawodu. W związku z tym największe wartości zatrudnienia $\mathrm{w}$ tej grupie wiekowej zanotowano $\mathrm{z}$ jednej strony w krajach o wysokim poziomie dochodu ma mieszkańca, a jednocześnie z wysokim odsetkiem ludności starszej (np. kraje skandynawskie, Wielka Brytania, Szwajcaria), a z drugiej strony w regionach rolniczych krajów Europy Środkowo-Wschodniej (Polska, Rumunia, Bułgaria) i niektórych krajów śródziemnomorskich (Portugalia, Grecja), gdzie osoby w wieku emerytalnym dalej prowadzą swoje gospodarstwa rolne. Najniższe wartości zatrudnienia wśród osób starszych zaobserwowano w regionach Francji, Hiszpanii, Węgier i Słowacji. Najwyższa stopa bezrobocia spośród badanego obszaru wystapiła w regionie śródziemnomorskim (Hiszpania, południowe Włochy, Grecja), we wschodnich landach Niemiec, w Słowacji i na Węgrzech oraz w Brukseli, natomiast najniższy poziom bezrobocia wystapił w regionach Austrii, Szwajcarii, Norwegii, Islandii, północnych Włoszech i północnej Szkocji.

W grupie mierników ekonomicznych największymi wartościami produktu regionalnego brutto na mieszkańca w Unii Europejskiej charakteryzowały się regiony stołeczne oraz regiony położone w Wielkiej Brytanii, Irlandii, krajach Beneluksu, południowych Niemczech, północnych Włoszech, a także Danii, Szwecji i Finlandii. Najniższy poziom PKB na mieszkańca charakteryzował regiony Bułgarii, Rumunii, Polski (zwłaszcza tzw. ściany wschodniej) oraz Słowacji, Węgier, Litwy i Łotwy Należy tu podkreślić, że wartość PKB na mieszkańca w Londynie była prawie 40-krotnie wyższa od analogicznego wskaźnika w regionie Severozapaden (Bułgaria). Podobny rozkład przestrzenny wystąpił w przypadku dochodów gospodarstw domowych, z tym że najwyższe wartości wystąpiły w południowych regionach Wielkiej Brytanii. Rozpiętość pomiędzy skrajnymi wartościami była jednak mniejsza (14-krotna). Najważniejszym regionem badawczo-rozwojowym w Europejskim Obszarze Gospodarczym jest Brunszwik. Charakteryzuje się on największymi wydatkami na sektor badawczo-rozwojowy. Znajduje się tu 27 instytucji naukowych oraz 250 przedsiębiorstw w sektorze wysokich technologii (od biotechnologii poprzez finanse po transport). Ponadto wysokie wydatki na badania i rozwój zanotowano w regionach skandynawskich oraz w południowych częściach Francji i Niemiec. Najniższy poziom wydatków na ten sektor, będący integralną częścią gospodarki opartej na wiedzy, wystąpił w regionach Rumunii, Polski, Bułgarii i Grecji. Regiony niemieckie (za wyjątkiem wschodnich landów) charakteryzują się najwyższą liczbą wdrożonych patentów na 1 mln mieszkańców, a rozkład przestrzenny tego wskaźnika jest zbliżony do wydatków na sektor badawczo-rozwojowy.

Pod względem rozwoju usług najwyższymi wskaźnikami liczby lekarzy na 100 tys. mieszkańców cechowały się, oprócz regionów stołecznych, regiony śródziemnomorskie. Jest to związane po części z wysokim odsetkiem ludności starszej w krajach śródziemnomorskich (np. Włochy to drugi najstarszy demograficznie kraj świata po Japonii z odsetkiem osób w wieku 65 lat i więcej przekraczającym 20\%, a w Ligurii nawet powyżej 30\%), 
atrakcyjnością klimatyczną tego obszaru i dużą liczbą uzdrowisk i obiektów sanatoryjnych oraz wysokim poziomem napływu osób starszych z innych krajów (migracje emerytów ze Skandynawii, Wielkiej Brytanii i Niemiec) i tworzeniem dla nich placówek opieki zdrowotnej. Niski wskaźnik poziomu opieki zdrowotnej wyrażony liczbą lekarzy na liczbę mieszkańców występuje głównie w regionach Europy Środkowo-Wschodniej. W zakresie infrastruktury transportowej największa gęstość autostrad występuje na gęsto zaludnionych obszarach nizinnych (kraje Beneluksu, Zagłębie Ruhry w Niemczech, otoczenie Londynu, Liverpoolu i Manchesteru w Wielkiej Brytanii). Brak autostrad zanotowano w regionach Polski (podlaskie, mazowieckie, warmińsko-mazurskie, pomorskie, lubuskie, lubelskie, świętokrzyskie), Rumunii (za wyjątkiem Bukaresztu i regionu Sud-Muntenia), Bułgarii (Severen-centralen), północnych części Skandynawii i Wielkiej Brytanii, a także Sardynii i Korsyki. W zakresie rozwoju turystycznego najwyższymi wskaźnikami intensywności ruchu turystycznego w przeliczeniu na liczbę mieszkańców charakteryzowały się najbardziej atrakcyjne regiony i ośrodki turystyczne krajów śródziemnomorskich, Austrii, Szwajcarii, a także rzadziej zaludnionych krajów skandynawskich i Islandii. Najniższy poziom ruchu turystycznego odnotowano w regionach Europy Środkowo-Wschodniej. Ostatni z przyjętych do analizy wskaźników dotyczył społeczeństwa informacyjnego i w tym zakresie najwyższy poziom dostępu do Internetu gospodarstw domowych zaobserwowano w Holandii, Islandii, krajach skandynawskich oraz Wielkiej Brytanii. Regiony, gdzie dostęp do Internetu ma mniej niż co trzecie gospodarstwo domowe, znajdują się w Bułgarii, Grecji oraz Rumunii.

Wyliczenia przyjętego taksonomicznego miernika syntetycznego pokazały, że najwyższym poziomem rozwoju regionalnego Europy charakteryzowała się Islandia (dane z tego zakresu dotyczyły okresu sprzed pojawienia się pierwszych oznak kryzysu finansowego), ponadto regiony stołeczne (Sztokholm, Oslo, Inner London, Île de France, Kopenhaga, Wiedeń oraz Górna Bawaria, Stuttgart, Hamburg w Niemczech, Berkshire, Bucks i Oxfordshire w Wielkiej Brytanii, Utrecht i Północna Brabancja w Holandii oraz Zurych w Szwajcarii. Najniższy poziom rozwoju regionalnego w świetle przyjętych mierników reprezentowały regiony Bułgarii, Rumunii, Grecji, wschodnich Węgier i Słowacji, Polski (m. in. ściana wschodnia i województwo świętokrzyskie), południowych Włoch, Estremadura w Hiszpanii, Alentejo w Portugalii oraz Sredisnja i Istocna Hrvatska (Chorwacja).

Podjęta próba typologii jednostek NUTS2 pod względem wybranych do analizy mierników rozwoju regionalnego w oparciu o taksonomiczną metodę k-średnich pokazała, iż istnieją duże różnice pomiędzy średnimi wartościami cech dla wydzielonych skupień. Największe dysproporcje wystąpiły w przypadku wartości PKB na mieszkańca (ponad 10-krotne) i ta cecha posłużyła do uszeregowania poszczególnych grup. W typie A znalazły się tylko cztery jednostki: Bruksela, Luksemburg i Inner London, charakteryzujące się także najwyższym dochodem gospodarstw domowych, najwyższym przyrostem naturalnym, najkorzystniejszą relacją pomiędzy ludnością produkcyjną i poprodukcyjną, najwyższym zatrudnieniem $\mathrm{w}$ usługach finansowych oraz największą liczbą lekarzy przypadających na 100 tys. mieszkańców. Z drugiej strony grupa ta charakteryzowała się najwyższym poziomem bezrobocia. Do typu B zaklasyfikowano regiony położone w 10 krajach Europy Zachodniej i Północnej (Danii, Szwecji, Finlandii, Niemczech, Austrii, Belgii, Holandii, Francji oraz Wielkiej Brytanii i Irlandii), w tym kilka regionów stołecznych (Wiedeń, Hovedstaden, Île de France, Sztokholm). Typ ten charakteryzował się najwyższym wskaźnikiem dostępu do Internetu, najwyższym wskaźnikiem zatrudnienia ogółem, osób starszych i w sektorze high-tech, największym wskaźnikiem wdrożonych patentów oraz wydatków na sektor B\&R, a także 


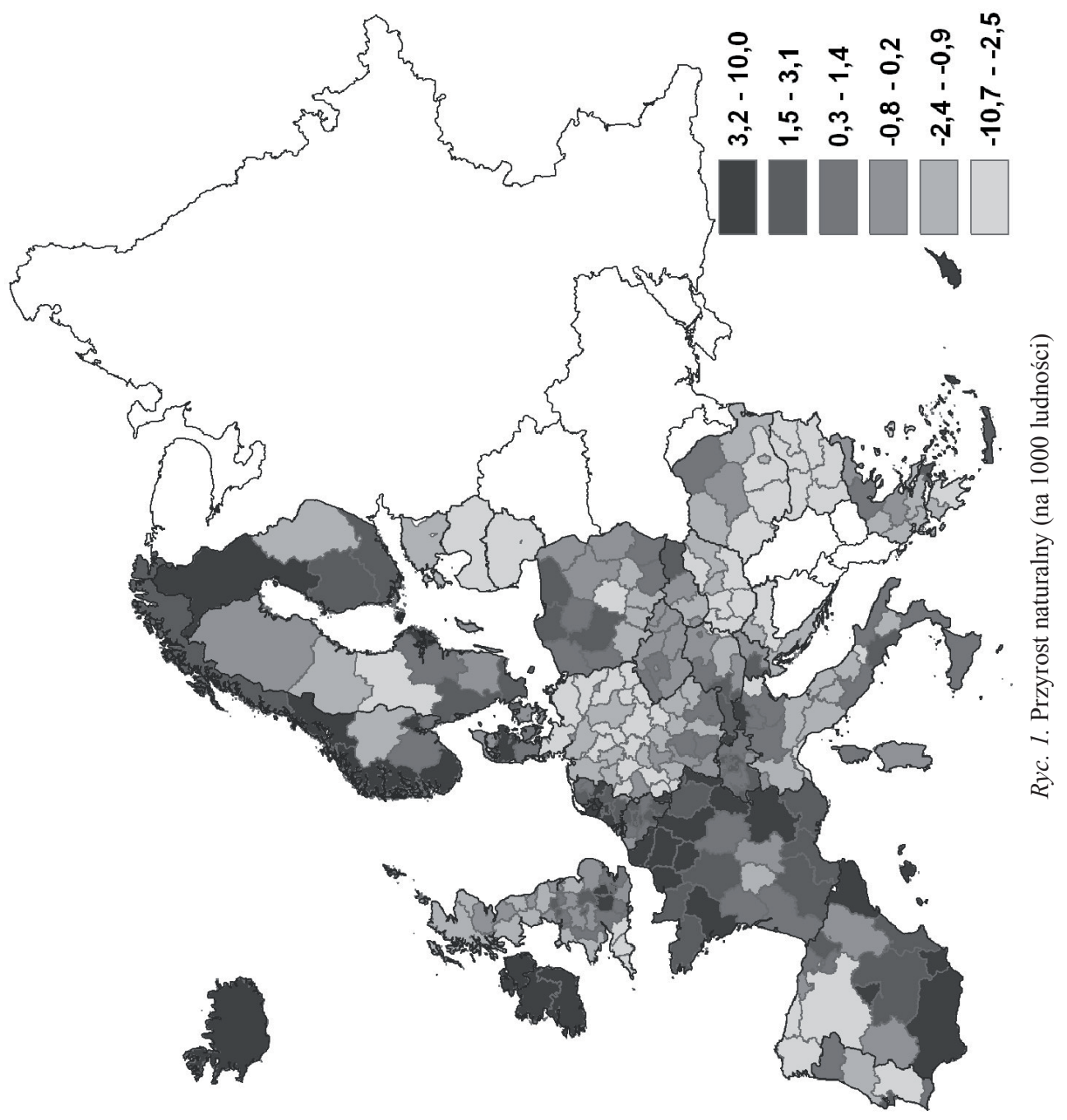




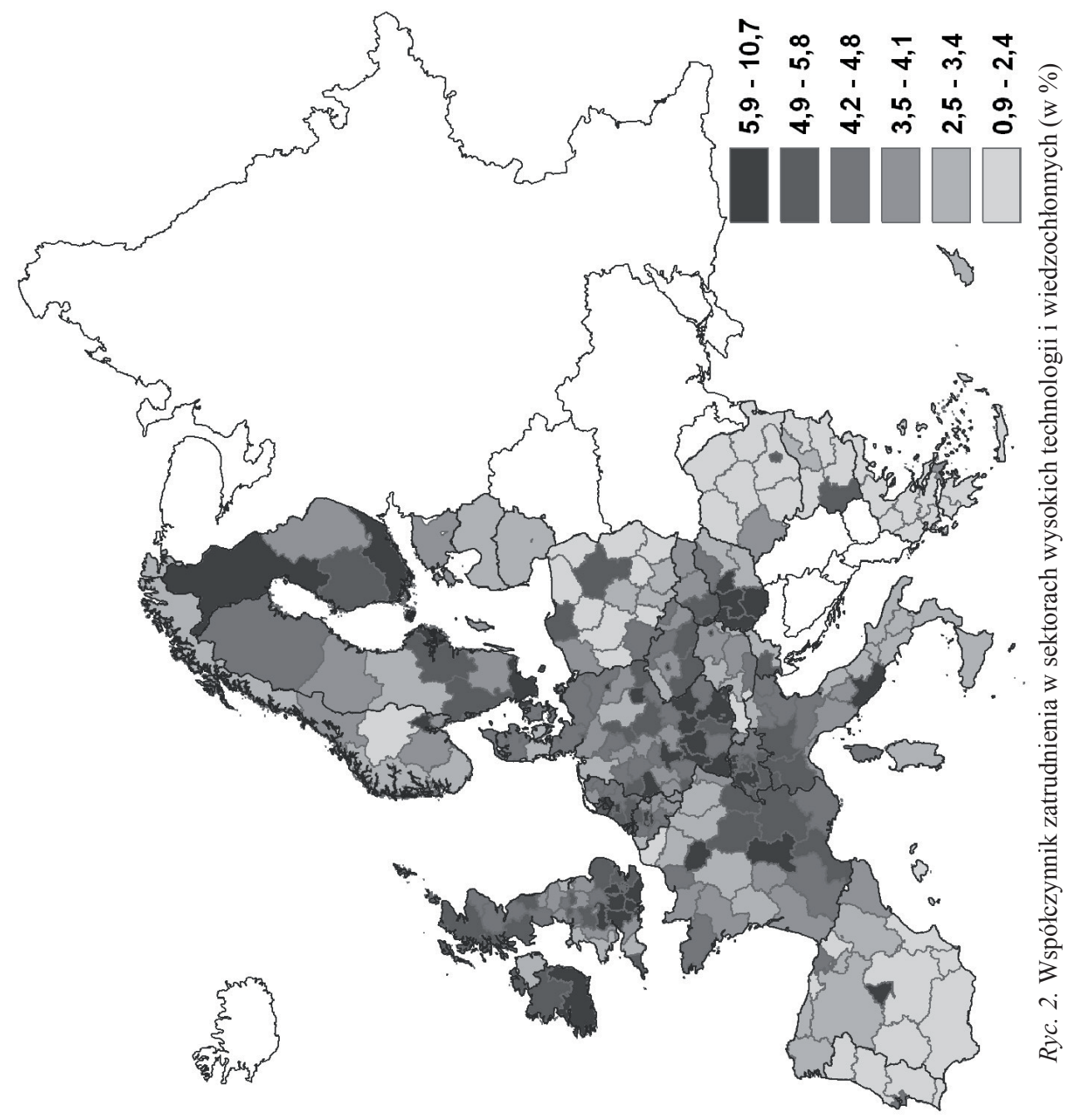




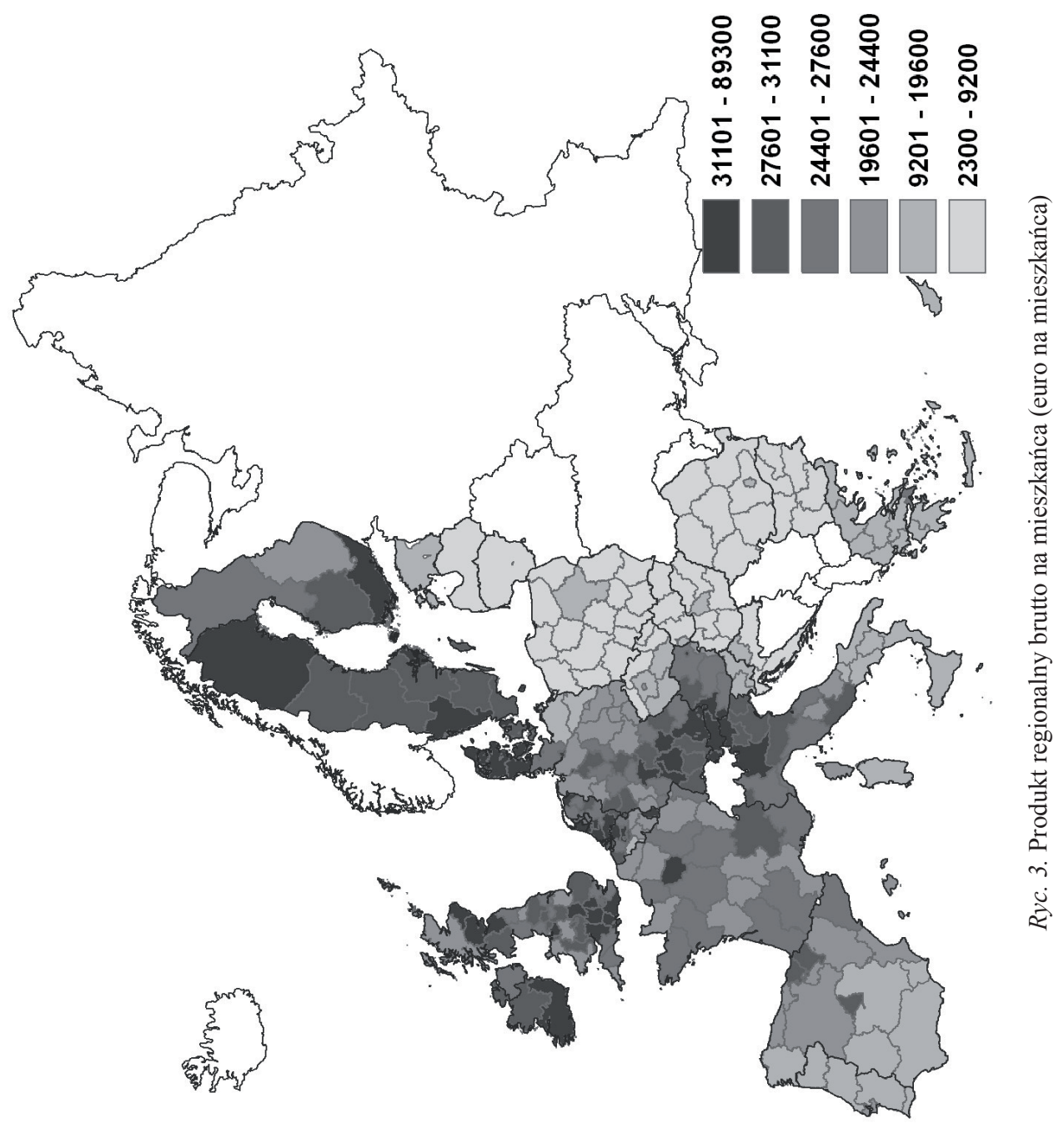




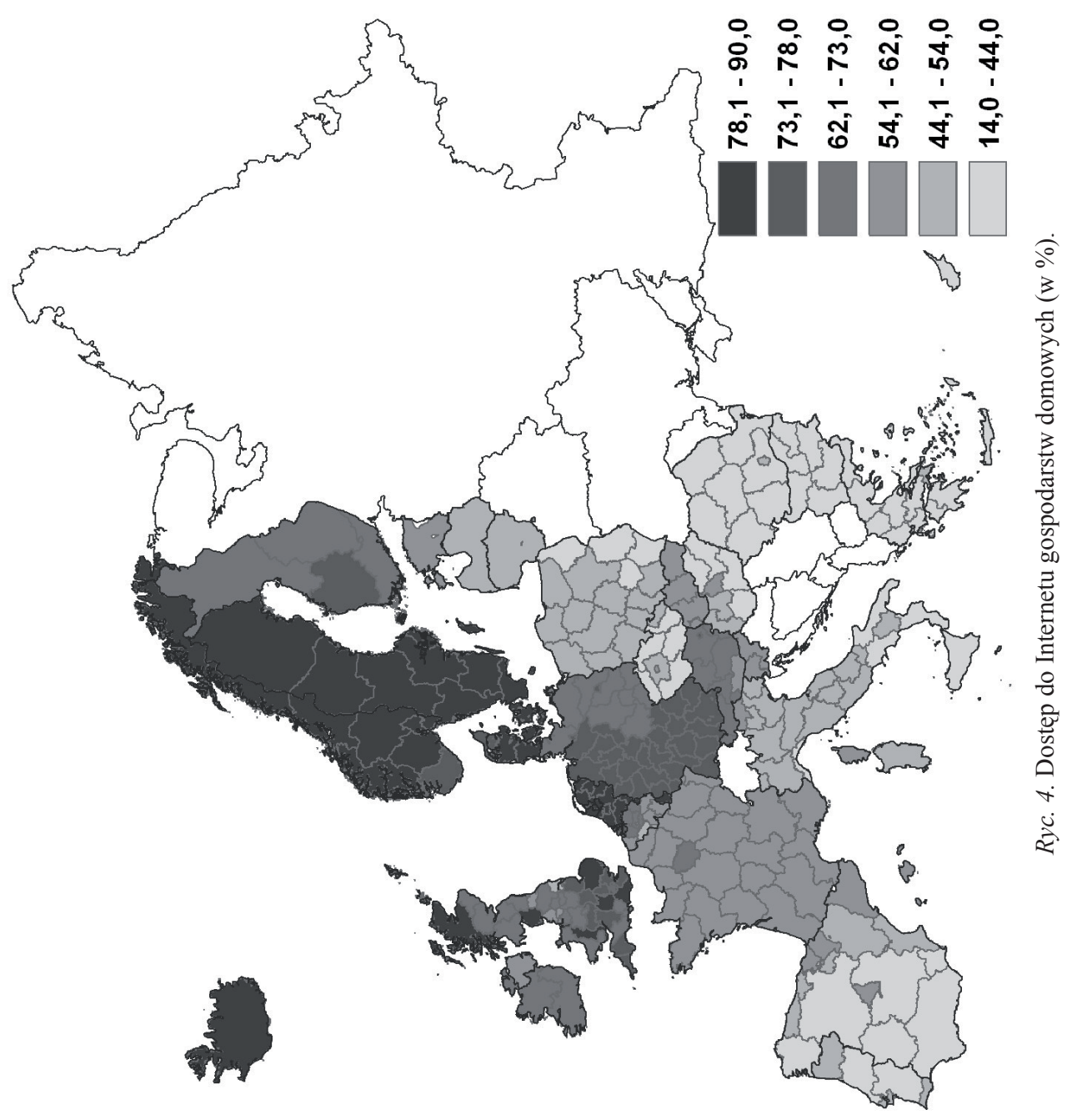




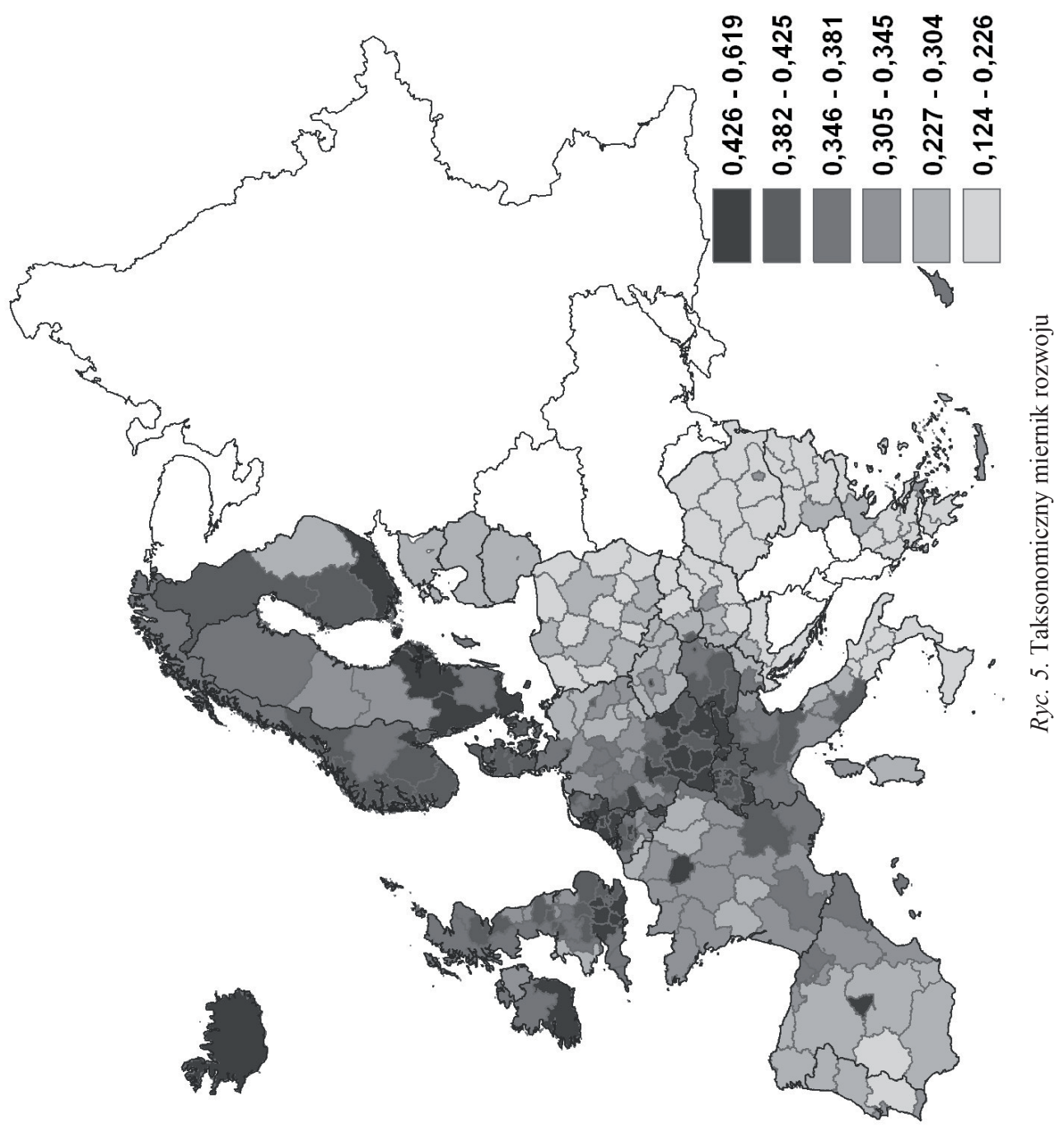




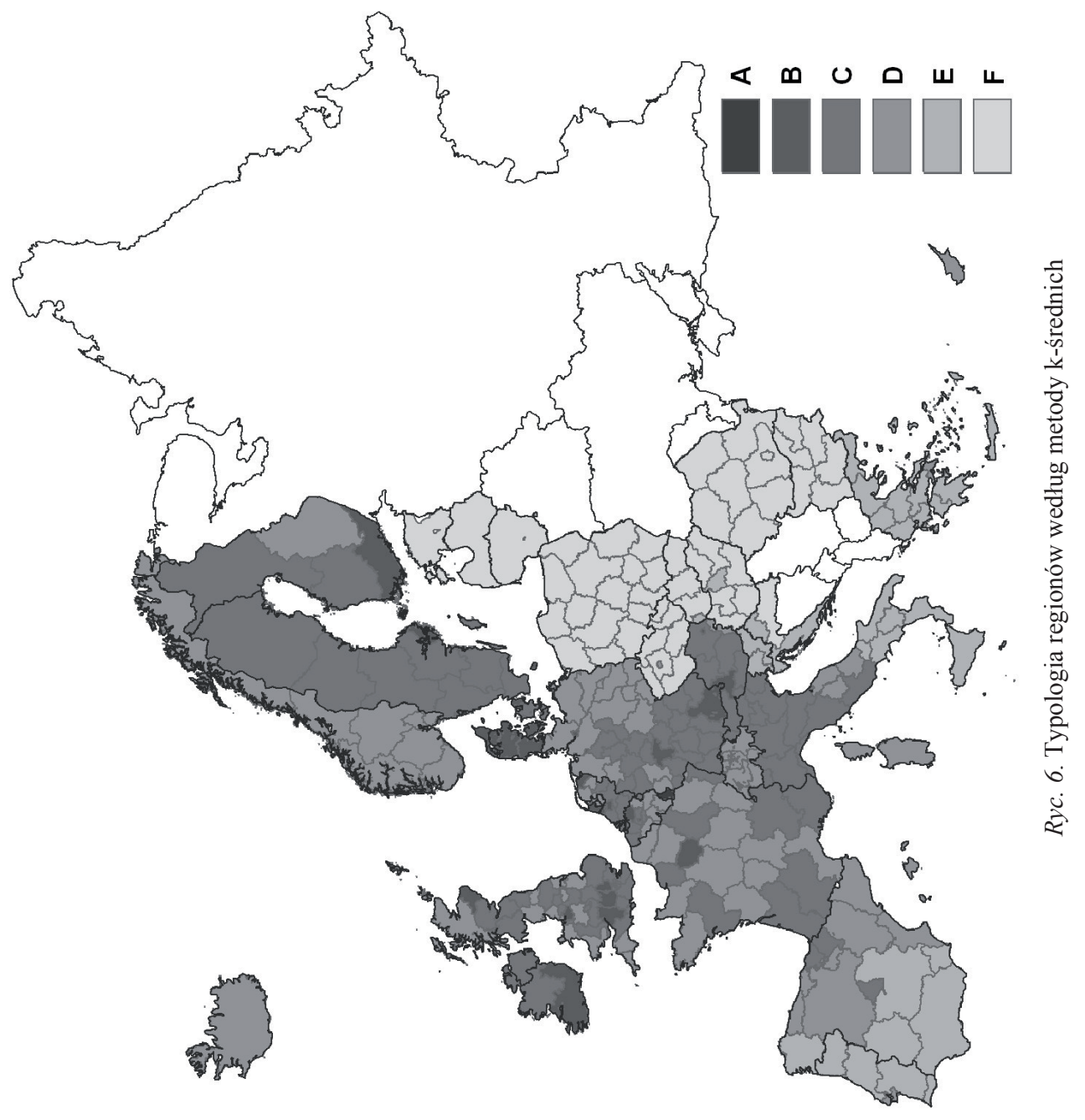


największą gęstością autostrad. Typ C, najbardziej liczny (88 jednostek), reprezentowały regiony położone m.in. w środkowych i południowych Niemczech, północnych Włoszech, Austrii, środkowej i północnej Wielkiej Brytanii, południowej Francji oraz Szwecji. Ponadto zanotowano tu także regiony stołeczne Włoch, Hiszpanii i Wielkiej Brytanii (Outer London). Typ D był najbardziej zróżnicowany wewnętrznie - wydzielone regiony położone były we wschodnich landach Niemiec, Norwegii, Szwajcarii, Francji, a także północnej Hiszpanii. Typ E był bardziej skoncentrowany przestrzennie i reprezentowały go głównie jednostki położone w regionie śródziemnomorskim (Portugalia, południowa Hiszpania i południowe Włochy oraz Grecja). Cechą charakterystyczną tego skupienia był ubytek naturalny ludności, najniższy dostęp do Internetu oraz najniższy wskaźnik aktywności zawodowej i wysoka stopa bezrobocia. Ostatni typ F reprezentowany jest przede wszystkim przez regiony Europy Środkowo-Wschodniej i odbiega od pozostałych, oprócz poziomu PKB na mieszkańca, także niską gęstością autostrad, największym ubytkiem naturalnym ludności, niskim wskaźnikiem intensywności turystycznej, niskim wydatkami na naukę i małym zatrudnieniem w sektorze finansowym.

\section{Podsumowanie}

Powyższa analiza potwierdziła istniejące różnice w poziomie rozwoju regionalnego Europy pomiędzy regionami wschodnimi a zachodnimi, największe dysproporcje wystąpiły w zakresie poziomu produktu regionalnego brutto na mieszkańca i dochodach gospodarstw domowych. Zakres czasowy opracowania pozwala na stwierdzenie, iż proces rozszerzania się UE prowadzi do pogłębiania się istniejących dysproporcji w obrębie Wspólnoty w zakresie ekonomicznym, a także demograficznym i społecznym. Najbardziej zaawansowanym obszarem pod względem rozwoju regionalnego w świetle wybranych mierników jest zurbanizowany pas zamieszkały przez blisko 90 mln ludności, ciągnący się łagodnym łukiem (stąd nazwa Europejski Banan, z ang. Blue Banana, Hot Banana, European Megalopolis lub European Backbone) od Anglii, poprzez kraje Beneluksu, północną Francję, zachodnią część Niemiec (Westfalię, Nadrenię, Bawarię), Austrię i Szwajcarię, po północne Włochy (Lombardię). Na obszarze tym, obejmującym takie ośrodki przemysłowo-usługowe, jak Londyn, Bruksela, Amsterdam, Frankfurt nad Menem, Stuttgart, Strasburg, Zurych, Turyn i Mediolan, znajdują się liczne uniwersytety i ośrodki badawczo-rozwojowe, parki technologiczne oraz instytucje finansowe. Ponadto wysoki poziom rozwoju regionalnego występuje w południowych regionach krajów skandynawskich oraz na Islandii.

Istniejące różnice w rozwoju regionalnym stanowią wyzwanie dla polityki regionalnej z jednej strony w zakresie zwiększania spójności ekonomicznej, społecznej i terytorialnej, a z drugiej podnoszenia konkurencyjności i atrakcyjności regionów za pomocą inwestycji w gospodarkę opartą na wiedzy, rozwijanie przedsiębiorczości, zwiększanie potencjału w dziedzinie badań naukowych i innowacji oraz rozwój infrastruktury transportowej i telekomunikacyjnej. 


\section{Literatura}

Avramov D., Maskova M., 2003, Active ageing in Europe, Population Studies, 41, 1, Council of Europe.

Bijak J., Kupiszewska D., Kupiszewski M., 2008, Replacement Migration Revisited: Simulations of the Effects of Selected Population and Labor Market Strategies for the Aging Europe, 2002-2052, Population Research and Policy Review, 27(3), 321-342.

Coleman D.A., 1992, Does Europe Need Immigrants?, Population and Work Force Projection, International Migration Review, 26 (98), s. 413-461.

Coleman D.A., 2000, Who's afraid of low support ratios? A UK response to the United Nations Population Division report of 'Replacement Migration', paper presented at the Expert Group Meeting on Policy Responses to Population Ageing and Population Decline, United Nations Population Division, New York, 16-18 October.

ESPON (European Spatial Planning Observation Network), 2007, Identyfikacja istotnych przestrzennie aspektów spoleczeństwa informacyjnego. Projekt ESPON 1.2.3. Raport końcowy, Uniwersytet Warszawski, Centrum Europejskich Studiów Regionalnych i Lokalnych (EUROREG). www. espon.pl/files/11_2/2/ESPON_1.2.3_RAPORT_FINAL_w.polska.pdf

European Commission, 2002, Europe's response to World Ageing Promoting economic and social progress in an ageing world. A contribution of the European Commission to the 2nd World Assembly on Ageing. Brussels, 18.3.2002 COM(2002)

European Commission, 2004, Low Fertility and Population Ageing. Causes, Consequences and Policy Options, RAND EUROPE. www.rand.org/pubs/monographs/MG206).

European Commission, 2005a, Cohesion Policy in Support of Growth and Jobs: Community Strategic Guidelines, 2007-2013. Brussels, 05.07.2005 COM(2005) 0299.

European Commision, 2005b, Green Paper. Confronting demographic change: a new solidarity between the generations. Brussels, 16.3.2005 COM(2005) 94 final.

Eurostat, 2004. Statistics of the information society in Europe 1996-2002, Office for official publications of the European Communities, Luxembourg.

Gawlikowska-Hueckel K., 2002, Procesy rozwoju regionalnego w Unii Europejskiej. Konwergencja czy polaryzacja?, Wydawnictwo Uniwersytetu Gdańskiego, Gdańsk.

Gawlikowska-Hueckel K., Zielińska-Głębocka A., 2004, Integracja europejska. Od jednolitego rynku do unii walutowej, Wydawnictwo C. H. Beck, Warszawa.

Głąbicka K., 2004, Spójność spoteczno-ekonomiczna w integrujacej się Europie, [w:] Spójność spoteczno-ekonomiczna - implikacje regionalne, red. K. Głąbicka, Radom.

Grabiński T., 1992, Metody taksonometrii, Wydawnictwo Akademii Ekonomicznej w Krakowie, Kraków.

Grabiński T., 2003, Analiza taksonometryczna krajów Europy w ujęciu regionów, Wydawnictwo Akademii Ekonomicznej w Krakowie, Kraków.

INSEAD, 2004, eEurope 2005 - a study of the degree of alingement of the New Member States and the Candidate Countries. Prepared for SAP by INSEAD. www.cisco.com/global/DE/pdfs/publicsector/sap report.pdf

Klasik A., Kuźnik F., 2001, Konkurencyjny rozwój regionów w Europie, [w:] Konkurencyjność miast i regionów, red. Z. Szymla, Wydawnictwo Akademii Ekonomicznej, Kraków.

Kudełko J., 2005, Rozwój regionalny a konkurencyjność regionów, [w:] Uwarunkowania rozwoju i konkurencyjności regionów, red. Z. Zioło, Instytut Gospodarki Wyższej Szkoły Informatyki i Zarządzania w Rzeszowie, Kraków-Rzeszów, s. 57-73.

Kudłacz T., 1999, Programowanie rozwoju regionalnego, Wydawnictwo Naukowe PWN, Warszawa.

Lesthaeghe, R., 2000, Europe's demographic issues: fertility, household formation and replacement migration. Working paper, United Nations Expert Group Meeting on Policy Responses to Population Ageing and Population Decline, New York, 16-18 October 2000. New York: United Nations. 
Kuciński K. (red.), 2009, Geografia ekonomiczna, Oficyna Wolters Kluwer Polska.

Kurek S., 2008a, Typologia starzenia się ludności Polski w ujęciu przestrzennym, Prace Monograficzne nr 497, Wydawnictwo Naukowe Akademii Pedagogicznej, Kraków.

Kurek S., 2008b, Spatial disparities in the changes in the population age structure of Poland in the context of the second demographic transition, Zeitschrift für Bevölkerungswissenschaft 33, 3-4, s. 271-292.

Kurek S., 2008c, Zróżnicowanie poziomu dzietności w Europie w świetle teorii drugiego przejścia demograficznego, [w:] Przeksztatcenia regionalnych struktur funkcjonalno-przestrzennych „Europa bez granic - nowe wyzwania”, red. D. Ilnicki, K. Janc, Wydawnictwo Uniwersytetu Wrocławskiego, Wrocław, s. 241-250.

Malina A., 2004, Wielowymiarowa analiza przestrzennego zróżnicowania struktury gospodarki Polski wedtug województw, „Zeszyty Naukowe Akademii Ekonomicznej w Krakowie”, seria specjalna: Monografie Nr 162, Wydawnictwo Akademii Ekonomicznej, Kraków.

Molle W., 2000, Ekonomika integracji europejskiej, Fundacja Gospodarcza, Gdańsk.

Saczuk K., 2003, A Development and Critique of the Concept of Replacement Migration, CEFMR Working Paper 4, Central European Forum For Migration Research in Warsaw.

Szymla Z., 2000, Determinanty rozwoju regionalnego, Wydawnictwo Ossolineum, WrocławWarszawa-Kraków.

Szymla Z., 2005, Podstawy badań rozwoju regionalnego, „Zeszyty Naukowe Wyższej Szkoły Ekonomicznej w Bochni”, nr 3, s. 101-111.

Urban D., 2008, Spójność społeczno-ekonomiczna jako wskaźnik asymetrii w rozwoju na przykładzie regionów Hiszpanii, [w:] Nierówności społeczne a wzrost gospodarczy. Gospodarka oparta na wiedzy, red. M. Woźniak, z. 11, Wydawnictwo Uniwersytetu Rzeszowskiego, s. 61-70.

United Nations, 2000, Replacement Migration: Is it A Solution to Declining and Ageing Populations? United Nations Population Division, New York.

World Economic Forum, 2009, The Global Information Technology Report 2008-2009. Mobility in a Networked World. www.weforum.org

Zioło Z., 2009, Przemiany społeczno-gospodarcze krajowych ukladów regionalnych $w$ latach 20002007, [w:] Potencjalne metropolie ze szczególnym uwzględnieniem Polski Wschodniej, red. Z. Makieła, „Studia KPZK PAN”, t. 125, s. 166-192.

\section{Spatial differences in the level of regional development in the European Union, on the basis of selected measures}

The aim of this article is to show spatial disparities in the level of regional socio-economic development of the European Union, basing on selected demographic, social and economic indexes derived from the Eurostat database. For the comparison, EFTA regions as well as some candidate countries (Croatia) were taken into account. The analysis was made with the help of taxonomic methods, namely the taxonomic development index as well as cluster analysis based on the k-means method.

The analysis confirmed existing disparities between eastern and western Europe, "old" and "new" European Union members, as well as between core and peripheral regions. The largest differences were recorded in terms of gross domestic product per inhabitant and household income. Having taken into account the period under study, it may be stated that the process of enlarging of EU leads to deepening of disproportion between its regions. The highest level of regional development was presented by the belt of urbanized area with the population of nearly 90 million, stretching from England through the Benelux countries, northern France, middle and southern Germany, Austria, Switzerland to northern Italy, called Blue Banana, Hot Banana, European Megalopolis or European Backbone. 
Existing demographic and socio-economic disparities between UE regions pose a challenge for regional policy to enhance its social, economic and territorial cohesion on one hand and to increase competitiveness between regions on the other, by investments in economy based on knowledge, increasing entrepreneurship, as well as increasing the potential in the R\&D sector and developing IT technology.

dr hab. Sławomir Kurek, prof. UP

Uniwersytet Pedagogiczny im. Komisji Edukacji Narodowej w Krakowie

Instytut Geografii

sgkurek@ap.krakow.pl 